Indedia $\quad \begin{aligned} & \text { InMedia } \\ & \text { The French Journal of Media Studies }\end{aligned}$

8.2. $\mid 2020$

What do Pictures Do? (In)visibilizing the Subaltern

\title{
Self-portrait as Epistemic Disobedience: Zanele Muholi's Somnyama Ngonyama
}

\section{Alexandra Poulain}

\section{(2) OpenEdition}

12 Journals

\section{Electronic version}

URL: https://journals.openedition.org/inmedia/2409

DOI: 10.4000/inmedia.2409

ISSN: 2259-4728

\section{Publisher}

Center for Research on the English-Speaking World (CREW)

\section{Electronic reference}

Alexandra Poulain, "Self-portrait as Epistemic Disobedience: Zanele Muholi's Somnyama Ngonyama", InMedia [Online], 8.2. I 2020, Online since 22 October 2021, connection on 28 October 2021. URL: http://journals.openedition.org/inmedia/2409 ; DOI: https://doi.org/10.4000/inmedia.2409

This text was automatically generated on 28 October 2021

(C) InMedia 


\title{
Self-portrait as Epistemic Disobedience: Zanele Muholi's Somnyama Ngonyama
}

\author{
Alexandra Poulain
}

\section{Introduction}

1 This article explores South African photographer and visual activist Zanele Muholi's ongoing project Somnyama Ngonyama and argues that it continues Muholi's lifework of decolonizing the canon of representations of Black bodies, especially Black female ${ }^{1}$ bodies. In their previous work, Muholi, whose chosen pronouns are "they" and "them," had documented the vulnerability and vibrancy of the lives of Black lesbians and trans men in South Africa, visiting crime scenes, weddings and funerals, and capturing scenes of intimacy between the members of their community. Muholi achieved worldwide fame with Faces and Phases, a project which started in 2006 and is ongoing. The work consists of a series of striking black and white portraits and seeks to create a visual archive for a community rendered invisible and expunged from the national narrative of anti-apartheid struggle by South Africa's violently homophobic culture, despite its liberal legislation. ${ }^{2}$ With Somnyama Ngonyama, Muholi turns the camera on themselves ${ }^{3}$. The first self-portrait in the series, Sthembile, Cape Town, 2002, ${ }^{4}$ was shot in Cape Town in 2012, but the concept for the full project did not emerge until 2014. Each image in the series stages a different version of Muholi, who uses a variety of framings, poses, backgrounds and props, so that each new shot destabilises and revises previous ones. New images are posted on Instagram, creating a chronological narrative of Muholi's life, with a variety of hashtags which frames them in a certain way, but when they are shown in galleries or museums each bears a title in isiZulu, Muholi's mother tongue, and in English translation. In the series' eponymous monograph, however, which features a selection of 204 photographs arranged unchronologically, the titles appear only at the end of the volume in the "list of plates" section and are listed in isizulu without the English translation. The photographs share a formal perfection and 
technical virtuosity and create complex puzzles which demand both emotional and intellectual engagement from the viewers. Creating a compelling yet enigmatic "archive of the self," the work is a decolonial intervention in the deeply political realm of representation.

2 As Stuart Hall, reading Fanon with Foucault, clarifies in his essay "Cultural Identity and Diaspora," colonial domination produced a body of pseudo-knowledge about the colonised which both Othered them in the eyes and discourse of the West and was internalised by the colonised themselves, giving them a degraded, forever inadequate self-image:

Not only, in Said's "Orientalist" sense, were we constructed as different and other within the categories of knowledge of the West by those regimes. They had the power to make us see and experience ourselves as "Other." Every regime of representation is a regime of power formed, as Foucault reminds us, by the fatal couplet, "power/ knowledge." But this kind of knowledge is internal, not external. It is one thing to position a subject or set of peoples as the Other of a dominant discourse. It is quite another to subject them to that "knowledge," not only as a matter of imposed will and domination, but by the power of inner compulsion and subjective conformation to the norm. ${ }^{6}$

3 The structure of oppression produced by this "knowledge," disseminated through a textual and visual canon, constitutes what decolonial thinkers call the "coloniality of knowledge," the epistemic correlative of Aníbal Quijano's foundational concept of the "coloniality of power." With Somnyama Ngonyama, Muholi expresses their (endlessly rehearsed) experience of being caught in a hegemonic system of representation that produces false, oppressive "knowledge" about Black female bodies and claims, in bell hooks' words, "a space for the transgressive image, the outlaw rebel vision"9 at the heart of the institutionalised visual archive of high art. Looking at specific images as well as at the project as an (as yet) unfinished series, I read the project as a sophisticated performance of "epistemic disobedience," ${ }^{10}$ which actively challenges the forms of knowledge ingrained in received representations of Black female bodies and invents a language of its own to create alternative images and tell other stories.

\section{Self-MaID}

In its sheer seriality, Somnyama Ngonyama, like Faces and Phases, responds to the near invisibility of Black bodies as subjects of representation in the history of Western painting (especially of portraiture) prior to the $20^{\text {th }}$ century. Muholi also repeatedly engages with one iconic exception. Marie-Guillemine Benoist's neoclassical Portrait of $a$ Negress, first shown in the Paris salon of 1800, bought by the French state in 1818 and now part of the Louvre's collection, shows a young Black woman sitting voluptuously on an armchair covered in blue velvet, calmly gazing at the viewer. She is draped in a white cloth (a simple sheet perhaps) held up with a thin red belt, which leaves her arms, shoulders and right breast exposed, and is wearing a white turban. Framing her very dark skin, the colours of the materials are those of the French Republic, and the exposed breast is often interpreted as an allusion to the allegorical figure of Marianne. Thus, the painting is read as a celebration of the abolition of slavery in postrevolutionary France in 1794 (it was to be reinstated in 1802 and only abolished again in 1848). The title of the painting became an object of embarrassment for the Louvre 
which changed it to Portrait of a Black Woman in the early 2000s. When the painting was shown in New York, Paris and Pointe-à-Pitre as part of the exhibition devoted to The Black Model from Géricault to Matisse in 2018-19, it was again renamed as Portrait of Madeleine, after the name of the young model. Her identity and personal history were retrieved by art historian Anne Lafont, who found her to be a freed slave from Guadeloupe, brought to France by the painter's brother and still living in his household as a servant after the abolition of slavery. ${ }^{11}$ The successive renamings of the painting, and especially the restoring of the model's identity (in fact only of her first name) were presented as decolonial gestures by the exhibition's curators, yet the conventional reading of the painting as a celebration of abolition and of Republican values was left largely unquestioned. Even though she is shown sitting on an armchair and gazing straight back at us, so that the picture breaches received codes of representation of Black female bodies and suggests a degree of agency, still her simple garb and half nakedness leave no doubt as to her status: she may no longer be a slave, but she is clearly a maid-a Black maid whose body is eroticised and displayed as an index of her master's wealth and status. The allegorical elements in the painting, turning her into a coded expression of Republican France's liberal values, perform an erasure of her individual experience and subjectivity which the restoration of her first name in the title, itself conveniently effacing the essentializing racism expressed in the original title, does not suffice to counter.

In Somnyama Ngonyama Muholi disseminates several allusions to Benoist's Portrait of a Negress, appearing in various poses dressed only in a white sheet and turban. In Sizile II, Gaborone, Botswana, 2014, ${ }^{12}$ Muholi's upper body appears against a textured background which recalls that of the Benoist painting. Their turban is cascading down the left hand-side of their face as in the painting, though their body is tilted slightly to the left, reversing the position of the original, and the photograph is framed so that their (presumably bare) right nipple is just out of range. A small, barred square of light, coming from outside, is reflected on their right shoulder, turning the image into a complex narrative puzzle: is this a prison cell? Muholi's distressed expression as their gaze meets ours, subtly revising "Madeleine"'s placid gaze in the painting, might indeed corroborate this reading. Against Benoist's narrative of freedom, Muholi tells a different story, one in which the Black female body is still literally in servitude (a servant, admittedly, rather than a slave-though her status as a free woman in postrevolutionary France turned out to be eminently precarious) and is confined within an allegorical system of representation which eroticises and objectifies her, ironically, in order to promote an ideological narrative of emancipation. Changing the framing of the image in order to leave their naked nipple out of frame, Muholi also reclaims a right to control the erotic potential of their self-representations.

6 A later work, MaID, Delaware, New York, $2017,{ }^{13}$ is an even more explicit citation of Benoist's painting. Here the photograph is an almost exact reconstruction of the painting as if it were reflected in a mirror, except for the background which is black with barely visible thin white stripes, an abstract inscription "abstracting" the body represented here from its original setting and ideological framework and transporting it through the looking-glass into Muholi's decolonial project of self-representation. The title of the piece, MaID (which Muholi uses for several other works in the series), one of the very few titles not in isizulu, has multiple implications that comment both on the original painting and on Muholi's recreation of it. The first meaning that comes to 
mind is simply the word "maid," which reassigns the "Negress" to her condition of servitude, demystifying the emancipatory narrative encoded in the original painting. Standing in for the "Negress," Muholi reminds us that domestic servitude is still the only status available to many Black women in the present day-indeed it was the occupation of their own mother Bester, their "Ma." The capitalisation of "ID," indeed, suggests the alternative pronunciation "Ma ID"-which one can read as "Ma's identity" or as "my identity"-the latter making a statement that Muholi's identity is self-made, that they claim the right to fashion and represent themselves on their own terms. Yet this statement of creative freedom is poised against another possible resonance of the capitalised letters "ID." As M. Neelika Jayawardane recalls, one of the means of surveillance and oppression of Black people during apartheid was the obligation to carry a passbook at all times:

Passbooks always included a photograph, intended to aid police and apartheid administrators in identifying individuals. The polaroid ID-2 camera, which had a "boost" button to increase the strength of the flash-allowing the user to better photograph dark-skinned people-was the chosen technology for photographing black South Africans for dompas, as passbooks came to be known. ${ }^{14}$

7 The title MaID, by encoding an allusion to an infamous instrument of surveillance, thus brilliantly deconstructs the Benoist painting's simplistic emancipatory narrative and connects it with a large visual archive of colonial, objectifying representations of Black bodies, deploying a sophisticated dialectic of freedom and containment, agency and objectification. Recreating the painting but reversing it, Muholi parodies the trope of the "self-portrait in a mirror" in Western painting and photography, assuming both the part of the "maid" and that of the "master" of representation. ${ }^{15}$

The emphasis on self-representation also speaks to other visual archives in which Black bodies are confined within epistemic systems that produce them as passive objects of "knowledge" for an extraneous audience. As Tamar Garb notes in her superb survey of contemporary South African photography, the tradition of ethnographic photography in South Africa was largely initiated in the 1860 s by the German anthropologist Gustav Fritsch "who was among the first to catalogue the 'natives' of South Africa for classificatory and 'scientific' purposes," ${ }^{16}$ producing an archive of close shots uncomfortably poised between expressive portraits and impersonal "prototypes." His work was continued by Alfred Martin Duggan-Cronin, an Irish employee of De Beers Consolidated Diamond Mines in Kimberley who produced an enormous body of idealizing photographs, presented in The Bantu Tribes of South Africa, published in four volumes between 1928 and 1954. As Garb explains:

The volumes, organised into eleven population groups, were intended to stand as "records" of declining communities whose "racial purity" and tribal customs were perceived as threatened by modernity and miscegenation. In order to preserve the image of traditional societies and subjects, Duggan-Cronin routinely supplied the appropriate accessories and costumes that his figures lacked from his store of "native" props, so that familiar items appear and reappear. ${ }^{17}$

Duggan-Cronin's photographs were thus elaborately staged fabrications which aimed to sustain Western "knowledge" about racial hierarchies and to encase "primitive" peoples in an Edenic fantasy world. Typically, Duggan-Cronin's subjects are half-naked and adorned with a paraphernalia of "tribal" necklaces and bracelets as well as a variety of elaborate headdresses; some wear animal skins or blankets; some carry 
"traditional" objects such as pipes, weapons or fly-whisks. At one level, Somnyama Ngonyama is an extensive parody of Duggan-Cronin's visual archive which questions its ability to produce any legitimate knowledge ${ }^{18}$. Muholi hardly ever photographs themselves wearing clothes; instead they use a wide range of materials and objects from everyday life, repurposed to function as jewels and headdresses. Some photographs are direct citations of Duggan-Cronin, like MaID in Harlem, African Market, $116^{\text {th }}$ Street, New York, 2015, ${ }^{19}$ in which they are wearing South African flywhisks around their neck like a scarf, leaving one breast exposed, along with a cowrie shell pendant from Ghana and Nigerian beads. The image wryly comments on the multiple cultural origins of the artefacts, improbably gathered together in Harlem after complex processes of economic exchanges and marketed indiscriminately as "African." "All that I am wearing," Muholi comments, "has been traded and negotiated; it requires capital. It's about the economy. It's about movement. It's about immigration. It's about import and export." ${ }^{20}$ With its jumble of disparate objects, MaID in Harlem parodies the staged fabrications of Duggan-Cronin's photographs (the title points out the artificiality of this self-portrait "made" to look like an ethnographic document) and counters its primitivist discourse by re-inserting the artefacts within the local and global dynamics of the "market" economy. Most images, however, parody the Duggan-Cronin archive not through direct citation, but by flouting the constructedness of photographs which use objects like theatrical props, repurposing them to create unprecedented, often zany compositions. In Sibusiso, Cagliari, Sardinia, Italy, 2015, ${ }^{21}$ Muholi has a wisp of straw around their neck and is wearing a rustic wooden stool on their head like a crown. In Basizeni I, Amsterdam, 2016, ${ }^{22}$ they have hung superposed cheap handbags around their neck like pendants and are carrying an elaborate heap of sunglasses on their head. Both images comment on the power of props to reconfigure bodies and condition our way of seeing them: Sibusiso constructs a narrative of bucolic simplicity, while Basizeni I creates a hybrid, Afrofuturistic creature out of the cheap goods offered by street vendors. Neither image gives an "authentic" version of Muholi nor yields any knowledge about them. The heaped-up sunglasses in Basizeni I, demultiplying Muholi's intense gaze, challenge the optical regime of ethnographic photography where the active gaze is the privilege of the Western viewer, the producer and receiver of knowledge about the African Other. The background is completely blurred, yet if we look closely, we see a whole urban industrial landscape of buildings, chimneys, and trees reflected in fragments in the sunglasses, a puzzle which only Muholi, who is facing it, can reconstitute.

Somnyama Ngonyama also seeks to challenge the way in which Black bodies are both invisibilised and, paradoxically, hypervisibilised by most conventional media which tend to represent them only within sensationalist narratives of spectacular violence and crime, while Black female bodies are rendered visible only if they conform to extremely rigid systems of norms. Julile I, Parktown, Johannesburg, 2016, ${ }^{23}$ shows Muholi lying naked on their stomach on a white carpet, beside a shelf of densely stacked newspapers. They are surrounded by a dozen inflated plastic bags, using some of them as pillows and hugging others, and are looking at us in obvious distress. The image is both extremely beautiful and completely enigmatic, and it takes Muholi's own explanations, disseminated in various interviews, to begin to make sense of it. In their conversation with Renée Mussai, Muholi comments:

With Julile, I was exploring personal issues while also thinking about how women's bodies are portrayed in the media, hence the newspapers stacked in the background. In 
this portrait, taken on December 10, 2016-three days before I underwent a major operation-I was in a reflective space and I felt anxious. The portrait is about a person thinking deeply. Julile, in isizulu, means “deep.” I didn't know if I was going to survive or not ... ${ }^{24}$

Elsewhere, we learn that the inflated plastic bags "represent the large fibroids she [sic] had removed from her uterus." ${ }^{25}$ The image thus poignantly confronts public with private knowledges, clichéd journalistic representations of Black female bodies with the stylised representation of a life-threatening disorder lodged "deep" inside this particular body. The stacks of newspapers form a wall beside Muholi, as if to contain them within a uniform narrative, but they are looking the other way, meeting our gaze with their own deeply reflective gaze, holding on to the inflated bags which tell a whole different story - a story that will never hit the headlines, told in a coded language that we may or may not learn. While it gives expression to an extremely personal anxiety (Muholi repeatedly mentions the "therapeutic" value of their work) the image also reflects critically on the political dimension of the project, which relentlessly interrogates the legitimacy of bodies of knowledge that attempt to confine Black bodies within epistemic systems that objectify and Other them. Indeed, many images in Somnyama Ngonyama make visible epistemic violence, materializing it as a "thick web" or veil of objectifying stereotypes, and variously challenge it, staging Muholi as the active, rebellious subject of representation.

\section{"I can't breathe"}

12 In Dalisu, New York, 2016, ${ }^{26}$ Muholi is staring at the camera in close-up, their face and upper torso just barely showing out of a tangle of dark wool which creates a kind of veil around their face and covers their shoulders, with one strand cutting across their face. They have applied their usual technique of enhancing contrast as much as possible in post-production, making their naturally dark skin appear even darker, so that the face and wool around it are differentiated only by their distinctive textures ${ }^{27}$. The whites of the eyes stand out, as does the face poised against a pale greyish background. Muholi's straightforward gaze invites the viewer's reciprocal gaze; their expression is hard to read, both fierce and suggestive of a certain weariness. The effect of the wool is ambiguous: it refracts the light beautifully and creates a stunning casing for Muholi's face, yet there is simply too much of it, so that they seem encumbered, impeded. Commenting on Dalisu in their conversation with Renée Mussai, Muholi points out that the work was taken after one of many unpleasant experiences in hotels, when they were treated with suspicion and disrespect on account of their skin colour:

Sometimes it feels as if you're inside a web-a web covering your face that you have to constantly peel back in order to breathe. Yet you are still giving yourself access to seeto check if what you are seeing or hearing is real. Dalisu talks about the feeling of being strangled alive. I felt entangled and confined, confused and angry. At the same time, it's an affirmation to myself and others like me-a call to action. A reminder to ourselves not to allow anyone to undermine us, or to be restrained by exterior forces or others. ${ }^{28}$

For Muholi the wool materializes the mass of racist preconceptions which literally "strangle alive" Black people in the allegedly post-racial world, in South Africa and beyond. Muholi's status as a highly acclaimed figure in the global artwork gives them access to art galleries and museums worldwide; yet paradoxically, the nomadic life they 
are thus allowed to lead as an artist and an activist constantly exposes them to false assumptions and hasty judgements that question the legitimacy of their presence in public space, especially in the privileged spaces of global modernity and mobility such as hotels and airports. Such epistemic violence (the violence inherent in the "knowledge" that produces this systemic othering) is experienced, excruciatingly, as "the feeling of being strangled alive." The conversation between Muholi and Mussai was recorded in 2017, but three years later, as I write, it takes on new, if not unexpected, resonances. It is no accident that George Floyd's dying words, "I can't breathe," repeated over twenty times as he was being literally "strangled alive," have become a slogan for the BLM movement globally. Muholi's visual metaphor expresses the agony of all those who find themselves gasping for breath under the weight of racist preconceptions and misrepresentations of Black bodies, but Floyd's death, and those of many others before him, remind us yet again that epistemic violence is intrinsically bound with lethal physical violence. Muholi's fierce expression in Dalisu (which translates as "make a plan") registers their invitation to collective resistance, their refusal "to be restrained by [the] exterior forces" materialized by the "web" of wool around their face, a theme which is repeated with multiple variations in Somnyama Ngonyama.

In South Africa, a substantial part of the apartheid legislation aimed to segregate space according to arbitrarily constructed racial categories and to monitor and limit the mobility of Black people. The endurance of racially segregated urbanism in postapartheid South Africa, almost thirty years after the dismantling of apartheid legislation, can be seen with dazzling clarity in the work of Johnny Miller, ${ }^{29}$ an American photographer who lives in Cape Town and uses drones to photograph zones of contact between heterogeneous urban areas, showing the dire contrast and sharp lines of demarcation between townships and privileged areas and thus making visible the geographical structures of inequality which are not visualized so glaringly when one is on the ground. While it is true that the end of apartheid gave Black South Africans a degree of spatial and economic mobility, unequal access to wealth continues to disadvantage mainly the Black population, so that the spatial demarcations visualised in Miller's photographs continue to reflect racial inequalities. As Muholi testifies, however, being made to feel like a trespasser on account of their skin colour is an injustice they experience routinely not just in South Africa, but also when traveling abroad: "In America, Europe, or Africa, the experience is never the same. But that judgement, that discrimination, that lingering sense that you are not supposed to be there, persists-having to continually justify your presence." ${ }^{30}$ One of the most poignant images in Somnyama Ngonyama is Kwanele, Parktown, Johannesburg, 2016, ${ }^{31}$ in which Muholi's exhausted face just barely emerges from a mass of whitish plastic wraps, the same material as Muholi uses to cover their suitcase when they fly. The image "responds to the experience of travelling through immigration at different airports where one is often racially profiled." ${ }^{32}$ It captures the exhaustion of having to endure the same humiliating routine over and over again at the end of a long flight, and the violent objectification which such a routine attempts to perform (turning them into an inert package) -yet defies such objectification with the tired but unflinching gaze which still demands that we engage with them on equal terms. The isizulu title translates as "it is enough." 
Another variation on the theme (among many more) occurs in Somnyama III, Paris, 2014, ${ }^{33}$ and Xiniwe, Chapel Hill, North Carolina, 2016. ${ }^{34}$ In both photographs, Muholi has two superposed travel pillows with prints vaguely suggestive of leopard skin around their neck, turned front side back so that they look like gigantic necklaces that threaten to throttle them. In Somnyama III ("dark"), Muholi is wearing a (barely visible) tight hat and a furry hood on top of it, around which an elaborate beaded pendant is tied. Their eyes are cast down and their chin is half buried in the travel pillows. The overall effect is that they are literally "packaged" in African kitsch and can barely move. The travel pillows work against the grain of their usual connotations, signifying constraint and immobility, but the image also suggests that what creates such restraint is the weight of preconceptions about "Africanness," and the way consumer society thrives on such clichés while perpetuating its surveillance and containment of Black bodies. In Xiniwe ("pressed"), Muholi is staring at us, frowning slightly, their neck disappearing into the travel pillows and their head ensconced in a bearskin hat which evokes those of the British Royal Guards, except for the glittering rhinestones cascading down the front. The image is bizarre and vaguely clownish, though Muholi's expression suggests a kind of incredulous dismay. Again, they seem incapable of movement, "pressed" as they are between the faux African pillows and the absurdly glamorized military hat, as if stuck between two distinct but complementary sets of stereotypes about Black bodies, those imposed by brutal colonial rule which continue to weigh down on Muholi and their generation, and the exoticizing fantasies of neo-colonial consumer society. Yet the surreal assemblage of props is in itself a fierce rejection of stereotypes. In its sheer buffoonery, the image reinscribes movement and play, delinks from conventional representations of Black bodies and promotes "the outlaw rebel vision" which bell hooks called for.

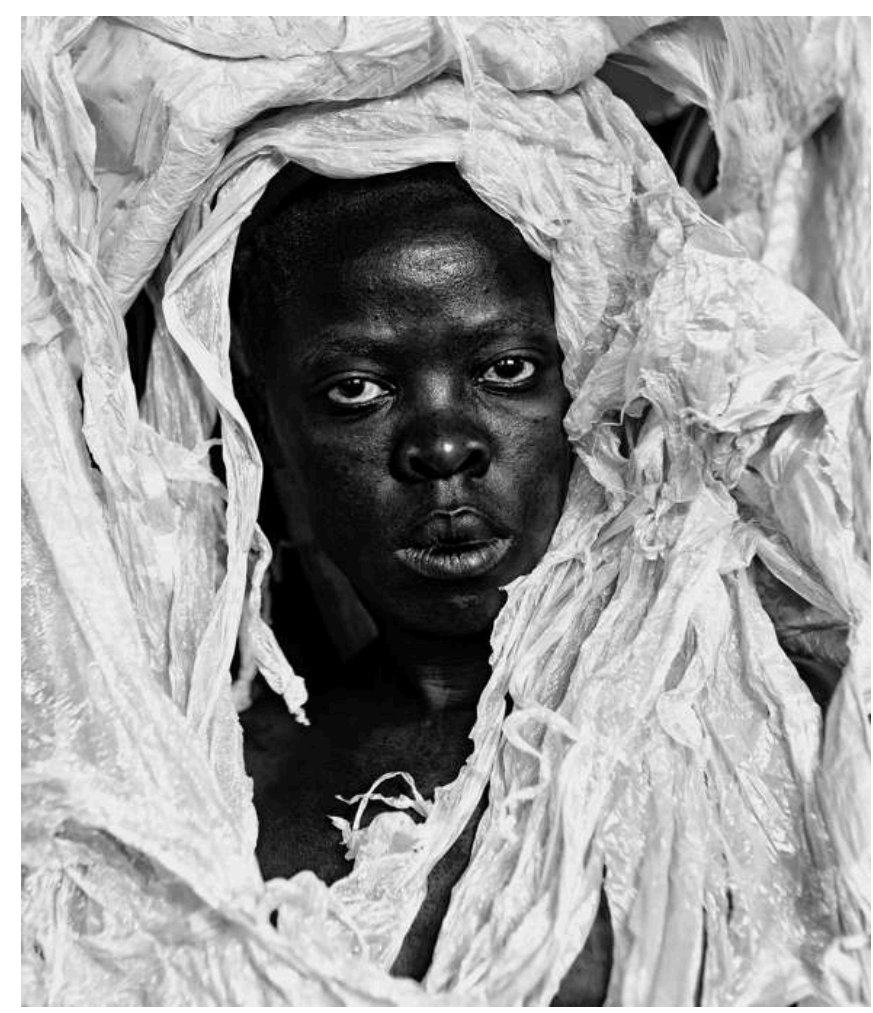

Fig. 1: Kwanele, Parktown, 2016 
A related series of works shows Muholi wearing various kinds of materials which are repurposed as veils. In Zamile, KwaThema, Gauteng, South Africa, 2016, ${ }^{35}$ they are covered in a striped blanket which leaves a thin aperture for them to peer through. They are standing in front of a similar blanket used as a hanging in the background. While such blankets were and still are common in South Africa, they were formerly used by the SAP (South African Police) and recall the prisons in which so many Black political prisoners were detained, often without trial, during apartheid.

Another image, Bayephi, Johannesburg, 2017, which shows Muholi behind bars, draped in a similar striped blanket and wearing another one as a headdress, was indeed shot at the women's prison on Constitution Hill. ${ }^{36}$ Both images conjure up the history of the anti-apartheid struggle and reinscribe the Black female body, and specifically the queer Black female body, within this narrative. Muholi has often commented on the way their work addresses the rampant homophobia in South Africa. Lesbians, trans men and gender-nonconforming people are especially vulnerable in this context and are routinely targeted by so-called "curative" or "corrective rape" (the practice which consists in raping-and often killing-lesbians to "cure" them of their homosexuality ${ }^{37}$ ). Despite an overtly LGBT+-friendly legislation, the myth that "homosexuality is unAfrican" is widespread in the country and the queer community has been consistently expunged from the nationalist narrative of anticolonial liberation. Clothing themselves in SAP blankets, Muholi, after Simon Nkoli, Beverley Palesa Ditsie and many other Black LGBTQ+ South African activists ${ }^{38}$, intervenes in this narrative and challenges its heteronormative assumptions. But while Bayephi comments explicitly on this context, Zamile, with its blanket repurposed as a veil, opens up other metaphorical spaces as well. "For me," Muholi comments, this blanket also represents a material for mourning, to remember Black people who suffered and perished in prison cells during apartheid, as well as those who suffer in the present: Black LGBTQIA individuals are raped, dismembered, bent, and brutally murdered daily in South Africa." ${ }^{39}$ The veiled figure of the mourner thus connects the victims of past and present in a public ritual of remembrance. Muholi's attitude in Zamile, fiercely peering at us from under the heavy blanket that all but hides them from view, also suggests that they are struggling for visibility, and thus also connects with the epistemic violence of stereotypes materialized by the wool, rope, plastic wraps or travel pillows in the previous series. Muholi's "veil" series recalls W.E.B. Du Bois' metaphor of "the Veil" in The Souls of Black Folks: the Veil is how white people see Black people, as if through a veil of prejudice which distorts their vision. Hence "double consciousness," the internal conflict suffered in a racist society by Black people, who come to see themselves as they are seen by whites, through the veil of racial prejudice. The book opens with the story of how Du Bois experienced the "revelation" of racial difference, as a little boy growing up in New England:

I remember well when the shadow swept across me ... In a wee wooden school-house, something put it into the boys' and girls' heads to buy gorgeous visiting-cards--ten cents a package--and exchange. The exchange was merry, till one girl, a tall newcomer, refused my card,--refused it peremptorily, with a glance. Then it dawned upon me with a certain suddenness that I was different from the others; or like, mayhap, in heart and life and longing, but shut out from their world by a vast veil. ${ }^{40}$

18 Experienced as a shadow that "swept across" him, the veil that others Du Bois is the terrifying materialization of what I have been referring to as "epistemic violence"-the 
thick web of racist misconceptions and distorted representations under which Black people suffocate. In Muholi's work, however, the veil photographs both express the suffering and alienation induced by such violence and, simultaneously, subvert stereotypical representations of Black (female) bodies.

In Bester IV, Mayotte, 2015, ${ }^{41}$ (one of several homages to Muholi's mother), Muholi is standing in front of a slightly blurred multi-coloured blind; their head and naked torso are covered with a garishly printed modern scarf and they have their eyes cast down, in a pose which parodies the Western iconography of the Madonna. The image thus both smuggles Muholi's body into the canon of Western "High Art" and demands similar deference for their mother Bester as for the revered figure of the Virgin Mary, who is almost always pictured as a white woman. In Thembeka I, Upstate New York, 2015, ${ }^{42}$ Muholi's veil is a long piece of white lace which covers their head and shoulders but leaves both their breasts exposed. They are at a two-thirds angle, their head bent forward slightly, but they are gazing straight at us. As Christine Eyenne remarks, the shot again evokes paintings of Virgin Mary, ${ }^{43}$ but the lace veil also works as a synecdoche of a bridal apparel-indeed as the only remnant of a bridal apparel after the bride has divested themselves of all the rest. If the veil is a signifier of epistemic violence, then this particular bridal veil suggests the complex web of assumptions and assignations placed on Black female bodies by a heteronormative, sexist, racist society: as an injunction to heterosexual marriage and chastity, it seeks to control this body's sexuality and signifies their willing participation in this regulatory mechanism, in exchange for the whole array of privileges which adherence to social norms affords. For Black women in South Africa, ${ }^{44}$ the stakes of paying allegiance to the heterosexual power structure are particularly high given the extraordinary level of violence unleashed daily against lesbians and gender nonconforming individuals ${ }^{45}$. Contrasting Muholi's very dark skin with the very white piece of lace, the shot implicitly comments on the racist undertones of the universal semiotics of bridal outfits, where white signifies sexual "purity" (itself a questionable misnomer for virginity). Muholi's pose, however, with their candidly exposed breasts and calm, challenging gaze, powerfully invalidates all the regulatory implications of the veil: this is a person who is in full control of their body and sexuality, who represents themselves on their own terms and will not defer to the authority of normative systems of representation. 


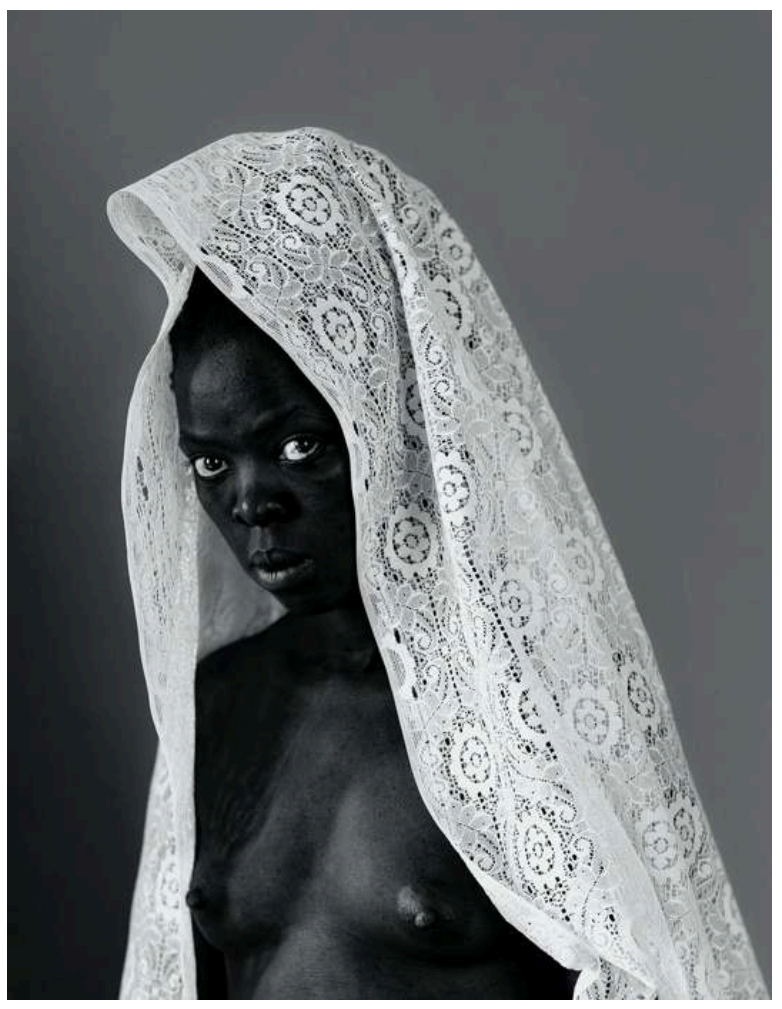

Fig.2: Thembeka I, Upstate New York, 2015

Two more related images in what I have called the "veil series" in the project deserve mention. In Thembeka II, London, $2014^{46}$ and Bester VII, Newington Green, London, 2017, ${ }^{47}$ Muholi is draped in a large black Issey Miyake scarf, a present, we learn in the concluding text in the monograph, from their friend Renée Mussai. Playing with the plasticity of the Miyake material, and on the contiguity of black skin and black cloth, both images create singular sculptures of live flesh and pleated silk. Thembeka II speaks to Thembeka I, preserving the iconic triangular shape of the veiled Madonna but replacing the white lace of virginal purity with luxurious black silk-another mourning veil, perhaps. In Bester VII, the sculpted shape which stands out against a pale greyish background is less familiar, a large, rounded cocoon of silk around the human body inside it, extending beyond the limits of the photograph's frame. To return to my reading of veils as metaphors of systems of "knowledge," ways of seeing that frame and contain, this particular veil speaks to common assumptions about the sorts of spaces and expectations deemed available to Black women. As Muholi has testified in the book and elsewhere, her mother Bester Muholi, like the vast majority of Black women during and since apartheid, was a domestic worker all her life: "her prison was someone's kitchen-different from Robben Island [where Mandela was imprisoned], but a prison nonetheless. She was unable to access other spaces, so the portraits also ask us to remember that Bester herself was locked into forty-two years of servitude. You don't own expensive things, as a domestic worker." ${ }^{48}$ The veil thus both points to the limited horizon of expectations-and in a very real sense, the restricted space-available to Black women in a racist, sexist society, and symbolically subverts this system of containment by giving Bester access to a whole world of luxury and travel (since the Miyake scarf connotes both Japan and London, and more generally the global designer industry). In many ways, the project performs a double agenda of escaping the restrictive space commonly allotted to Black female bodies and breaking into new 
spaces, delinking from hegemonic systems of knowledge in a protracted gesture of epistemic disobedience.

\section{Escape game}

21 In the final section of this essay, I argue that many photographs in the series represent not so much a pose as an ambiguous movement of appearing or disappearing. One recurrent technique used in the series, as I have mentioned earlier, is to enhance the contrast of the images. When Muholi photographs themselves against a dark background, the effect is to blacken their skin so that they seem to be either merging into, or emerging from, the background. In Zodwa, Paris, $2014,{ }^{49}$ Muholi's body is facing the camera in front of a completely black background, gazing at something which we cannot see to their right. The image is decentred so that their left arm and shoulder are out of range. They are wearing only a large breast-piece of cowrie shells and are wearing their hair in a short afro. The heightened contrast makes the breast-piece stand out strikingly, while the dim light subtly brings out the different textures of skin and hair. Perhaps the most intriguing aspect of the work is that the right side of Muholi's body, and the back of their head, are so dark that they literally seem to be absorbed by the surrounding darkness. They could be appearing out of the dark or fading into it. In Sandile, Parktown, Johannesburg, $2015,{ }^{50}$ Muholi is looking at us with their head tilted backward slightly. They are wearing a round rim hat, a denim shirt with the collar turned up, and a necklace of flat shiny beads that resemble coins. The shirt, hat and contours of the face are very dark and fade into the dark background on the right side of the photograph, so that only the features of the face, the buttons of the shirt and the necklace are clearly visible. On the right side of the image, the outline of the figure is barely discernible in the shadow, and the outline of the whole face merges into the wider rim of the hat. The square framing of the photograph is poised against the perfect circle of the hat, and because of this geometrical construction, our brain is able to recreate the part of the hat rim which fades into the dark background. The expression of Muholi's face is like a challenge, but again, the story behind the image is for us to reconstruct. They could be appearing in a space where they are not expected or disappearing from a space of confinement. Against global suspicion of Black bodies and efforts to bar them from certain privileged spaces and to confine them in other spaces, both physical and epistemic, Muholi uses their dark skin to instil movement and ambiguity in their photographs and refuses to be either cancelled out or boxed in. 


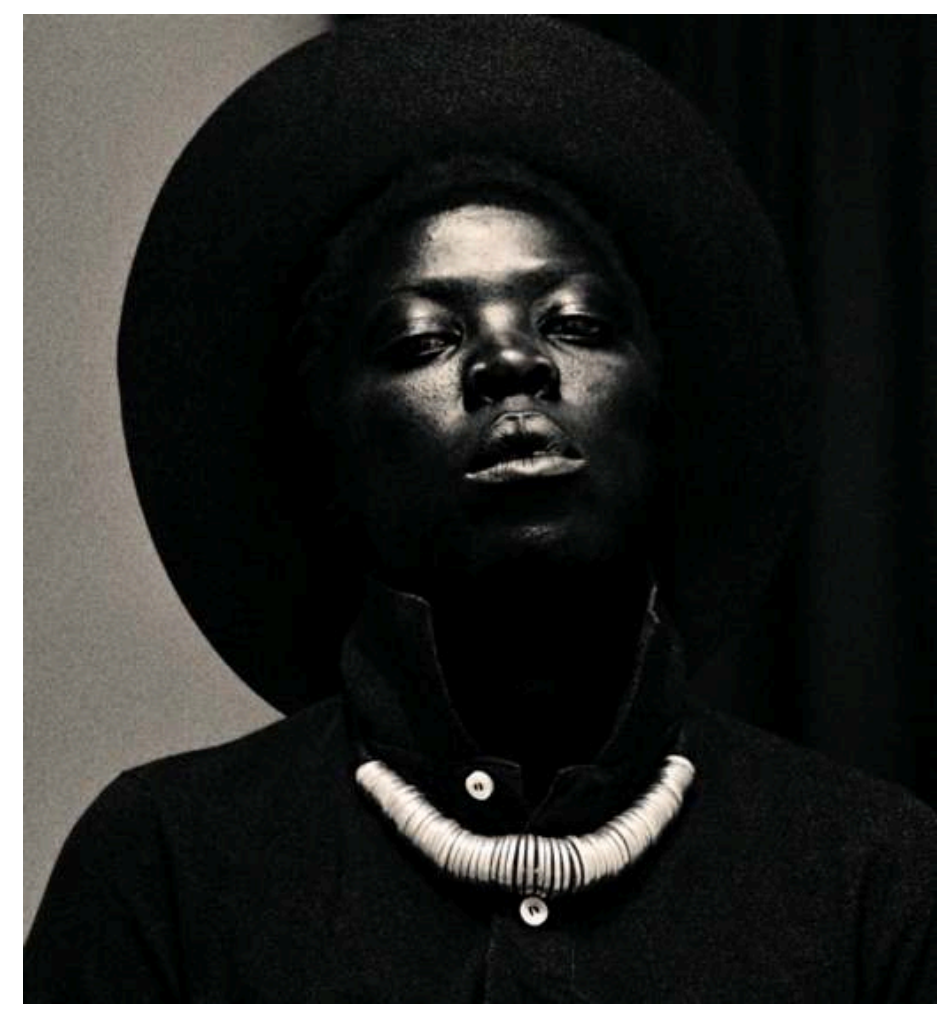

Fig. 3: Sandile, Parktown, 2016

This ambiguous game of appearing or disappearing is staged dramatically in ZaBo II, Kyoto, $2017^{51}$ and Bhekisisa, Sakouli Beach, Mayotte, 2016. ${ }^{52}$ The former (whose title is a condensation of Zanele/Bonsai) shows a large Japanese pine tree at night, its dense foliage sometime parting so that white patches of light appear here and there. At first this is all that one sees, but soon one realises that two of these white patches are in fact a pair of eyes, and that a black face and torso are "planted" in the image, barely visible. The shot suggests facetiousness, but it has serious implications, as Muholi indicates:

In $Z a B o$, I felt comfortable being there, in the tree. I wanted to create that confusion that I have produced in previous portraits, where you see nothing apart from my eyeballs. You have to look for the body... to scrutinize the environment, to "discover" me. In this instance, I am taking control, to say, "Look for me." And when you find that body, what do you see? What are you even looking at-or looking for, rather? It's a choice between how exposed you want to become, or not wanting to be seen at all. ${ }^{53}$

Muholi reminds us that while invisibility is a form of social death for Black people and all marginalised communities, visibility means heightened vulnerability. This is the double bind that the whole project attempts to negotiate. Controlling how they choose to be "exposed" (in the photographic sense and otherwise) is a decisive political intervention which restores subjectivity and agency to the body in the image and asks the viewer to actively engage with them without assuming they can ever know anything about them. The next image in the book, Bhekisisa ("Look closely") is taken in broad daylight and spans a double page. At first all we see is a desolate landscape of sand and rocks, with dark pools of water here and there. It takes a conscious effort to "look closely" and make out Muholi's naked body laid out on the rocks. Their eyes are closed and their lips half open-they could be sleeping or dead. Muholi comments that the shot "is about bodies lost at sea, those bodies that we read about in the newspaper, 
washed ashore," and of course it is no accident that it was shot in Mayotte, which thousands of migrants from the Comoros Islands attempt to reach on precarious boats every year. The work performs both an appearing (a migrant body is "washed ashore") and a disappearing (Muholi's body escapes us and fades into the environment), against the grain of all colonial uses of photography that freeze, expose and control their objects.

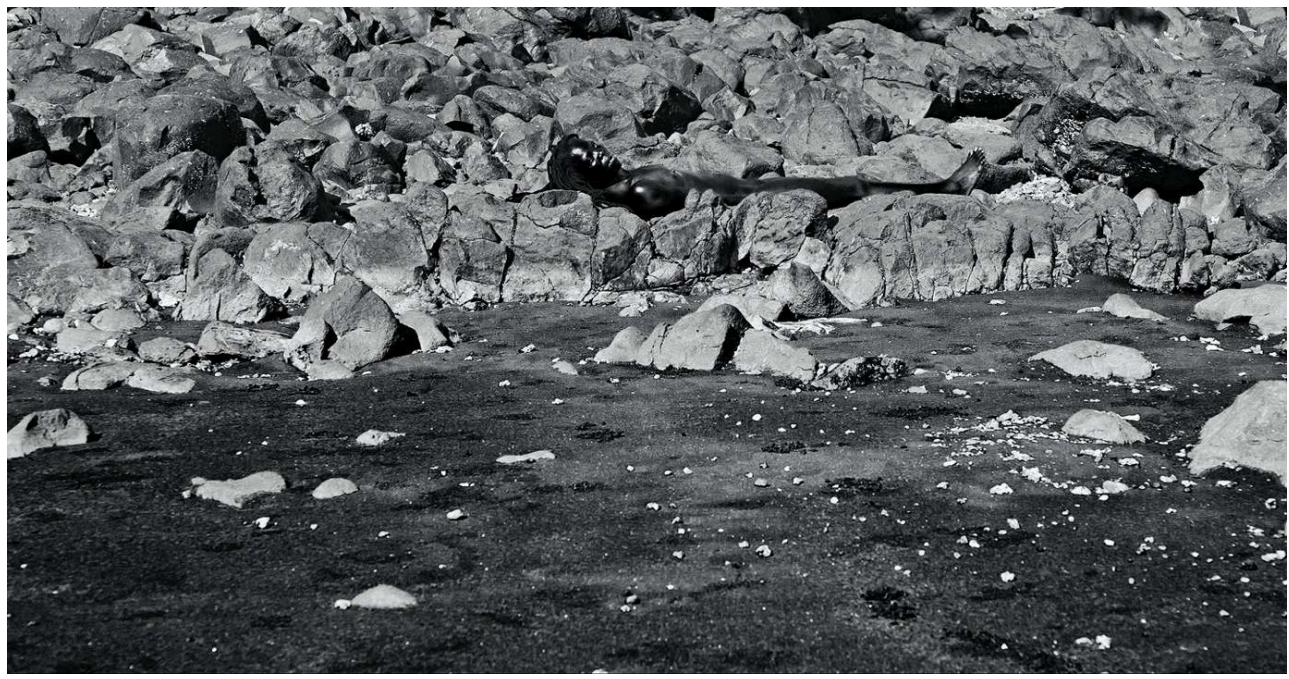

Fig.4: Bhekisisa, Sakouli Beach, Mayotte, 2016

Bhekisisa also performs another kind of disappearing: in embodying an anonymous migrant washed ashore, Muholi leaves behind their own persona and takes on another. Some photographs are in homage of people they knew and loved, who have passed away. I have mentioned some of the "Bester" photographs already, in which Muholi embodies their dead mother, often in images that recall Bester's painful life as a domestic servant. In Bester I, Mayotte, 2015, ${ }^{54}$ Muholi has an extraordinary crown made of clothes pegs. They have a peg pinching each of their earlobes, and another peg attaching the rug which covers their shoulders, and they have painted their lips white with toothpaste. In Bester V, Mayotte, 2015,5 their face and naked upper body again almost fading into the darkness; what catches the light most is a shiny headdress made of metallic scouring pads. In both cases, banal objects which were part of Bester's life as a maid are repurposed and assembled in unprecedented ways with Muholi's body to evoke and honour Bester's lifelong suffering. In the Basizeni series, Muholi variously embodies their dead sister, and Mfana, London, 2014, ${ }^{56}$ which shows Muholi's face framed with long braided hair, staring ahead as if in a mirror, is a tribute to their brother who died at an early age in a car accident. Mourning, remembering the dead, is envisaged as an act of becoming, whereby Muholi's body becomes merely a portal for the all ghosts that their work honours. Many of these ghosts were not familiar to her but are honoured as anonymous subjects of pain. In Thulani II, Parktown, Johannesburg, 2015 ${ }^{57}$, Muholi is facing the camera, bare-chested, wearing only a hard hat surmounted with a pair of goggles. The image recalls the "Marikana massacre" of 2012, when the SAPS, acting on government orders, opened fire on miners who were striking for better wages and working conditions, killing thirty-four of them and injuring another seventy-eight. Yet, as Muholi comments, "no one has been held accountable, no justice given." ${ }^{58}$ With their bare torso Muholi's body produces a sense of utter vulnerability in the face of brutal state violence. The title translates as "Be silent," which is of course 
the opposite of what the work is doing-recalling the memory of the martyred miners of Marikana, or perhaps calling them back, reincarnating them by the power of Muholi's performance so that they can tell their own story. Other images also conjure up specific associations with the South African context. In Ziphele, Parktown; Johannesburg, 2016, ${ }^{59}$ Muholi's body is trapped in a pile of black tyres which come up to her neck; one of them is hoisted up behind their head to form a sardonic halo. The image references the horrendous torture of necklacing ${ }^{60}$ used against alleged Black informants during apartheid. Again, Muholi effaces themselves to become the anonymous, martyred subject of pain. In Bhekezakhe, Parktown, Johannesburg, 2016, ${ }^{61}$ they are wearing a vaguely South-East-Asian looking pointed hat and collar which we realise, on second sight, to be made of zip ties. As Muholi explains, these are commonly used by SAP in lieu of handcuffs. ${ }^{62}$ As in Ziphele, ordinary objects routinely (mis)used to inflict violence are again repurposed and brought into unprecedented configurations with Muholi's body, which disappears in its private capacity and returns as the generic body of pain. In these works, Muholi's photography comes close to performance art, insofar as the artist and activist uses their body as the raw material of their work to explore, inhabit and make visible situations of oppression and violence. "Unselfing" the subject of the project, Muholi's "archive of the self," then, doubles up as an archive of the suffering, resilience and resistance of marginalised Black bodies.

Conversely, Muholi's works perform the appearing of marginalised Black bodies into spaces to which they usually have no access. This is true in the very basic sense that Muholi's status as an internationally renowned artist gives them access to prestigious museums and galleries around the world, and they often take along a large crew of collaborators and members of their community who often have no experience of patronising the institutionalised spaces of contemporary art. As Mark Gevisser reports: "For Performa last year, Muholi brought with her twenty people to New York, including drag artists, contemporary dancers, a phalanx of documenters, the mother of a murdered lesbian and even a personal gynaecologist." ${ }^{63}$ The images themselves also perform a kind of intrusion into prohibited symbolic or epistemic spaces, a breaking into representational traditions which have historically been inaccessible to Black female bodies. Several commentators have pointed out that the head-and-shoulders view, the two-thirds or three-quarters pose and the intent look in many of the selfportraits connect them parodically to a whole tradition of Western portraiture from the Renaissance and baroque eras, as if Muholi were forcing themselves into an exclusively white canon. ${ }^{64}$ I have also mentioned the "veil" series and its explicit connection to the "Madonna" tradition in Western painting.

Finally, in Ntozakhe II, Parktown, Johannesburg, 2016, ${ }^{65}$ the cover image in the monograph, beautifully printed on shiny silver cardboard, Muholi impersonates a very dark Statue of Liberty, whose spiky hair has been replaced by a crown of black scouring pads, recalling the earlier Bester $V$ image. Defamiliarising a familiar icon, the shot asks uncomfortable questions about the alleged universality of the statue's symbolism. In Muholi's words:

What is the color of the Statue of Liberty? ... I was thinking of black women who were civil and human-rights activists and criminalized for their activism, and how today so many women are prisoners in their own lives, neither free in their domestic situations nor in society at large-especially women of color. ${ }^{66}$ 
While the shot makes the rather obvious point that "liberty" is not a condition accessible to all women, and perhaps underlines the implication of the United States and of other "First World" countries in perpetuating the subservience of women of colour globally, it also inserts a Black female body into one of the most visited sites in the world, turning the invisible Black body of servitude into one of the iconic sights of Western modernity. Performing a paradoxical game of appearing and disappearing, Muholi's self-portraits thus escape the hold of objectifying systems of knowledge, embrace self-erasure in order to embody invisible others, and break into the privileged spaces of Western visuality to trouble the regime of omissions and exclusions which sustains it.

\section{Conclusion}

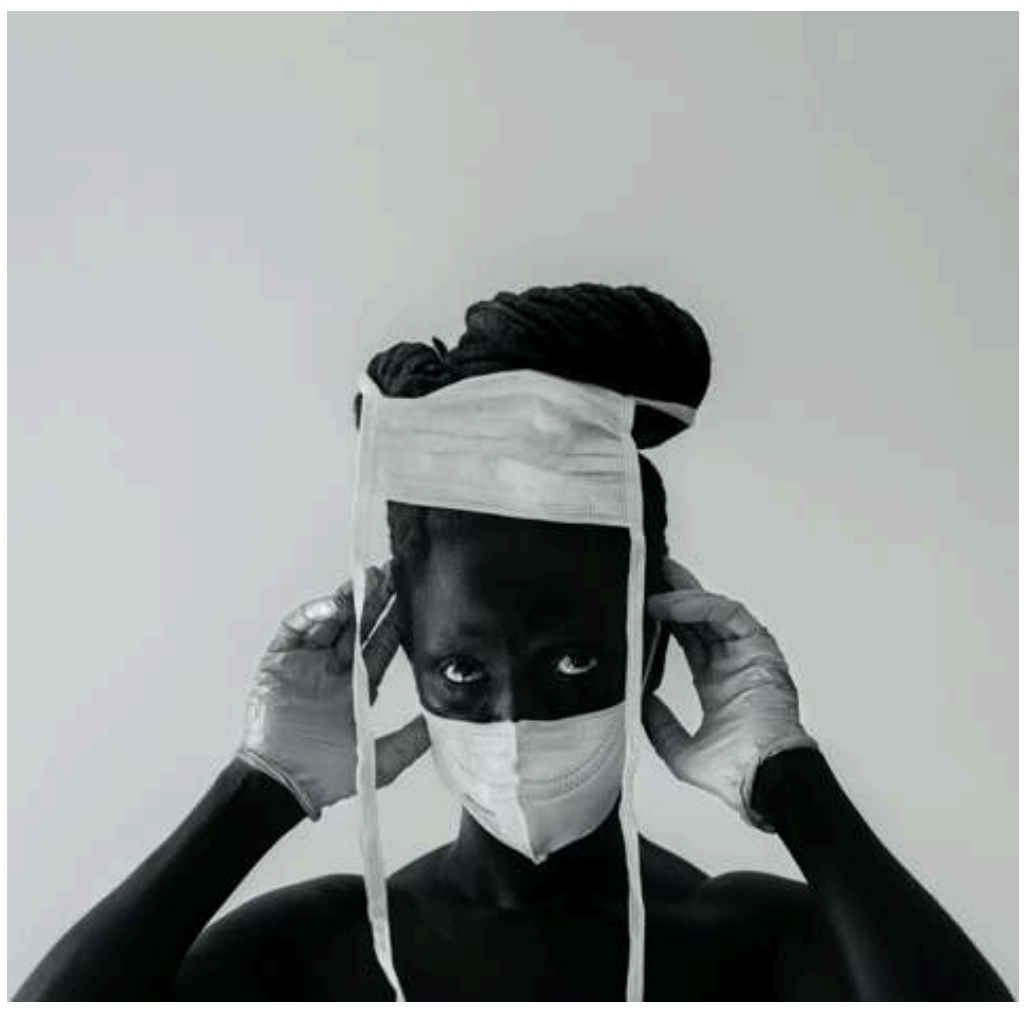

Fig.5: Aphelile IV, Durban, 2020

On 21 May 2020, Muholi posted a new work called Aphelile IV, Durban, $2020^{67}$ on Instagram, taken a month earlier while they were in lockdown in Durban due to the Covid-19 crisis. They are wearing latex gloves and a white mask covering the lower part of their face; their hair is done in an elaborate asymmetrical bun around which, absurdly, another face mask has been tied, framing their forehead, eyes and the upper part of their nose in an imperfect square that replicates and destabilises the larger square frame of the photograph. The title of the image translates as "They are gone," which invites us to read it as another gesture of mourning, probably for those who had no access to gloves and masks and have already passed away. While lockdown was experienced by billions of people around the world, the image is a reminder that South Africa has so far been by far the worst hit country in Africa; a year after the photograph was taken it is currently being hit particularly severely by the third wave of infections, 
while the country's population remains largely unvaccinated ${ }^{68}$. An article about the pandemic published in Time Magazine on 10 July 2020 remarked that "Some of the worst-affected countries are among the world's most unequal. South Africa leads them all on that measure, with the pandemic exposing the gap in care," ${ }^{69}$ but the piece failed to state the obvious-that inequalities in South Africa are largely distributed along racial lines. Confinement may have been a widely shared experience, but the image implicitly reminds us that it was by no means shared on equal terms, and that some, indeed, "are gone". Literal confinement also speaks to other forms of confinement which I have mentioned throughout this article, from the actual experience of prison which is such a crucial part of the history of equal rights activism in South Africa and elsewhere to the confinement of domestic service, to epistemic confinement-the experience of being stuck within a hegemonic, alienating system of knowledge and representation. The skewed frame within the frame is a formal reminder of the embedded structure of confinement to which so many Black people, especially women, are exposed. Yet the sheer existence of the image testifies to the power of Muholi's work to reflect on the present moment and respond to it by making art, using their body to explore the vulnerability of marginalised Black female bodies and to relentlessly challenge the dominant visual regime which thrives on their invisibility.

Anna, Cara. "Coronavirus Cases Spike in South Africa and India, Exposing Inequalities in Virus Treatment," Time Magazine, 11 July 2020. <accessed on 24 July 2020> Du Bois, W.E.B. The Souls of Black Folks, 1903; Oxford: Oxford University Press: 2007. Eyenne, Christine. "On 'Thembeka I." In Zanele Muholi, Somnyama Ngonyama (New York: Aperture, 2018): 158-60.

Farber, Leora. "Dark Play. The Ethnographic Archive as Site of Embodiment in Zanele Muholi's Somnyana Ngonyama Series." Visual Anthropology Review, 36-1 (2020): 40-63. Garb, Tamar. "Figures and Fictions: South African Photography in the Perfect Tense." In Figures and Fictions. Contemporary South African Photography, edited by Tamar Garb (Göttingen: Steidl and V\&A, 2011): 11-85.

Gevisser, Mark. "Zanele Muholi: Dark Lionness," The Economist, 1843 Magazine, 5 June 2018. <accessed on 24 July, 2020>

Gobodo-Madikizela, Pumla. "Remorse, Forgiveness, and Rehumanization: Stories from South Africa." Journal of Humanistic Psychology, 42-1 (2002): 7-32.

Hall, Stuart. "Cultural Identity and Diaspora." In Identity, Community, Culture, Difference, edited by Jonathan Rutherford (London: Lawrence \& Wishart, 1990): 222-37.

hooks, bell, Black Looks. Race and Representation, 1992; New York and London: Routledge, 2015.

Imma, Z'étoile. "(Re)visualizing Black lesbian lives, (trans)masculinity, and township space in the documentary work of Zanele Muholi." Journal of Lesbian Studies, 21-2 (2017): 219-241. <accessed on 27 April, 2021>

Jayawardane, M. Neelika. "Heeding the Dark Lionness's Call." In Zanele Muholi, Somnyama Ngonyama (New York: Aperture, 2018): 170-174.

Keam, Siobhan. "Penetrating the Impossible Space. Zanele Muholi's 'Somnyama Ngonyama' in London," Artthrob, 28 August 2017. <accessed on 19 July, 2020>

Khoza, Mbali. "Seeing Blackness through Black Expressive Culture: A Reading of Zanele Muholi's Somnyama Ngonyama - Hail the Dark Lioness." Athens Journal of Humanities \& Arts, 8 (2021): 1-25. <accessed on 27 April, 2021>

Lafont, Anne. Une Africaine au Louvre en 1800. La Place du modèle. Paris: INHA, 2019. 
Lahiri, Madhumita. "Crimes and Corrections: Bride Burners, Corrective Rapists, and Other Black Misogynists." Feminist Africa 15 (2011): 121-34.

Makhubu, Nomusa M. "Violence and the cultural logics of pain: representations of sexuality in the work of Nicholas Hlobo and Zanele Muholi." Critical Arts: South-North Cultural and Media Studies, 26-4 (2012): 504-524. <accessed on 27 April, 2021>

Mignolo, Walter. "Delinking. The rhetoric of modernity, the logic of coloniality and the grammar of de-coloniality." Cultural Studies 21: 2-3 (March-May 2007): 449-514.

- "Epistemic Disobedience and the Decolonial Option." Transmodernity: Journal of Peripheral Cultural Production of the Luso-Hispanic World 1:2 (Fall 2011): 44-66.

Athi Mongezeleli Joja. "New Work by Zanele Muholi." Africana.org, 03/02/16. <accessed on 27 April, 2021>

Muholi, Zanele. Somnyama Ngonyama. New York: Aperture, 2018.

Riedwaan Moosage. "A Prose of Ambivalence: Liberation Struggle Discourse on Necklacing.” Kronos 36-1 (2010). <accessed on 26 April, 2021>

Müller, Brian Michael. "The mark of the mask: queer neo-ethnographies and double consciousness in post-apartheid South Africa." Safundi, 2019. <accessed on 25 April, 2021>

Mussai, Renée. "Archive of the Self. Renée Mussai in Conversation with Zanele Muholi." In Zanele Muholi, Somnyama Ngonyama (New York: Aperture, 2018): 176-196.

Quijano, Aníbal. “Coloniality and Modernity/Rationality." Cultural Studies 21: 2-3 (March-May 2007): 168-178.

Saner, Emine. “'I'm scared. But this work needs to be shown': Zanele Muholi's 365 protest photographs," Guardian, 14 July 2017. <accessed on 22 July, 2020>

Strauss, Helene. "Spectacles of Promise and Disappointment: Political Emotion and Quotidian Aesthetics in Video Installations by Berni Searle and Zanele Muholi." Safundi 15-4 (2014): 471-495. <accessed on 27 April, 2021>

Thomas, Kylie. “Zanele Muholi's Intimate Archive: Photography and Post-apartheid Lesbian Lives." Safundi: The Journal of South African and American Studies 11, no. 4 (2010): 421-36.

Unequal scenes. <accessed on 18 July, 2020>

van der Vlies, Andrew. "Queer knowledge and the politics of the gaze in contemporary South African photography: Zanele Muholi and others." Journal of African Cultural Studies, 24:2 (2012): 140-156.

\section{NOTES}

1. Muholi's choice of pronouns indicates a wish to distance themselves from conventional binary gender assignations, and as many scholars have acknowledged, their work also tends to challenge, complicate or queer heteronormative understandings of gender. See for instance Z'étoile Imma, “(Re)visualizing Black lesbian lives, (trans)masculinity, and township space in the documentary work of Zanele Muholi," Journal of Lesbian Studies, 21-2 (2017): 219-241. <accessed on 27 April, 2021>Nomusa M. Makhubu also comments on the frequency of "bodies whose gender is visually ambiguous." Nomusa M. Makhubu, "Violence and the cultural logics of pain: 
representations of sexuality in the work of Nicholas Hlobo and Zanele Muholi," Critical Arts: South-North Cultural and Media Studies, 26-4 (2012): 504-524, 508. <accessed on 27 April, 2021> While this work is pursued in some images in the Somnyama Ngonyama series, many others return to a more conventionally gendered use of the artist's body to comment on modalities of violence targeted specifically against Black female bodies in South Africa and beyond.

2. For a discussion of queer representability in the photographic archive see for instance Andrew van der Vlies, "Queer knowledge and the politics of the gaze in contemporary South African photography: Zanele Muholi and others," Journal of African Cultural Studies, 24:2 (2012): 140-156.

3. Muholi had created numerous self-portraits prior to this project. For instance, they had inserted several images of themselves within the series Faces and Phases, which documents the community black lesbians and trans men in South Africa and globally. However, the self-portraits in Somnyama Ngonyama tend to distance themselves from the more naturalistic aesthetics of earlier works.

4. Zanele Muholi, Somnyama Ngonyama (New York: Aperture, 2018), 9.

5. The phrase is used as the title of the conversation between Muholi and curator of the London Gallery Aperture APB Renée Mussai which features at the end of the monograph. Renée Mussai, "Archive of the Self. Renée Mussai in conversation with Zanele Muholi," in Muholi, Somnyama Ngonyama, 176. For an extensive discussion of the archival dimension of Somnyama Ngonyama see Leora Farber, "Dark Play. The Ethnographic Archive as Site of Embodiment in Zanele Muholi's Somnyana Ngonyama Series," Visual Anthropology Review, 36-1 (2020): 40-63.

6. Stuart Hall, "Cultural Identity and Diaspora," in Identity, Community, Culture, Difference, ed. Jonathan Rutherford (London: Lawrence \& Wishart, 1990): 225-26.

7. See for instance Walter Mignolo, "Delinking. The rhetoric of modernity, the logic of coloniality and the grammar of de-coloniality," Cultural Studies 21: 2-3, (March-May 2007): 449-514.

8. Aníbal Quijano, "Coloniality and Modernity/Rationality," Cultural Studies 21: 2-3 (March-May 2007): 168-178. This landmark article was first published in Spanish in 1990.

9. bell hooks, Black Looks. Race and Representation (1992; New York and London: Routledge, 2015): 20.

10. Walter Mignolo, "Epistemic Disobedience and the Decolonial Option," Transmodernity: Journal of Peripheral Cultural Production of the Luso-Hispanic World 1:2 (Fall 2011): 44-66.

11. Anne Lafont, Une Africaine au Louvre en 1800. La Place du modèle (Paris: INHA, 2019).

12. Muholi, Somnyama Ngonyama, 175.

13. Muholi, Somnyama Ngonyama, 191.

14. M. Neelika Jayawardane, "Heeding the Dark Lionness's Call," in Muholi, Somnyama Ngonyama, 171.

15. The inclusion of the painter's mirror in the self-portrait typically draws attention to the creative process and the fact that it rests on the painter's gaze, sometimes reproducing the distortion induced by early convex mirrors, as in Parmigianino's Self-Portrait in a Mirror (ca. 1524), thus underscoring the artist's mastery. Muholi's image plays with this tradition by recreating but reversing a well-known painting, as if Muholi were painting their own image reflected in a mirror.

16. Tamar Garb, "Figures and Fictions: South African Photography in the Perfect Tense," in Figures and Fictions. Contemporary South African Photography, ed. Tamar Garb (Göttingen: Steidl and V\&A, 2011), 18.

17. Garb, "Figures and Fictions," 21.

18. In his article on Muholi and Kelebogile Ntladi, Brian Michael Müller uses the term "queer neo-ethnography" to refer to "the method by which queer subjects re-purpose conventions of ethnography and ethnographic photography. It encapsulates the ways in which queer subjects read, use and create images, texts and archives to narrate their own stories with nuance and insight thus presenting a counter to the dominant narrative of queer existence." Brian Michael 
Müller, "The mark of the mask: queer neo-ethnographies and double consciousness in postapartheid South Africa," Safundi, 2019, 3 (note 12).

19. Muholi, Somnyama Ngonyama, 89.

20. Mussai, "Archive of the Self," 187.

21. Muholi, Somnyama Ngonyama, 51.

22. Muholi, Somnyama Ngonyama, 54.

23. Muholi, Somnyama Ngonyama, 142-43.

24. Mussai, "Archive of the Self," 190.

25. Emine Saner, “'I'm scared. But this work needs to be shown': Zanele Muholi's 365 protest photographs," Guardian, 14 July 2017 <accessed on 22 July, 2020>

26. Muholi, Somnyama Ngonyama, 103.

27. The practice of digitally enhancing contrast in self-portraits has been read as a form of photographic version of blackface, despite Muholi's insistence that "there are no preservatives" (such as black paint) involved in the image-making process. Athi Mongezeleli Joja, for instance, sees this practice as "congealing" blackface aesthetic and dismisses "its assumption that reproducing the stereotype, somewhat diminishes its proclivity to degradation." (Athi Mongezeleli Joja, "New Work by Zanele Muholi," Africana.org, 03/02/16. <accessed 27 April, 2021> I rather sympathize with Mbali Khoza's view that "[w]hile Muholi's blackening of their skin can, at first glance, be interpreted as the reproduction of these anti-black tropes, it does the contrary. It draws our attention to how skin was and still is the primary medium through which the body is racialized." Mbali Khoza, "Seeing Blackness through Black Expressive Culture: A Reading of Zanele Muholi's Somnyama Ngonyama - Hail the Dark Lioness," Athens Journal of Humanities \& Arts, 8 (2021): 1-25, 16 <accessed on 27 April, 2021>

28. Mussai, "Archive of the Self," 179.

29. The pictures can be seen on the website of Miller's project "Unequal Scenes" (accessed 2020-07-18). The project started with pictures taken in South Africa but now also includes work taken in other countries around the world.

30. Mussai, "Archive of the Self," 178-79.

31. Muholi, Somnyama Ngonyama, 79.

32. Mussai, "Archive of the Self," 179.

33. Muholi, Somnyama Ngonyama, 163.

34. Muholi, Somnyama Ngonyama, 112.

35. Muholi, Somnyama Ngonyama, 56.

36. See Siobhan Keam, "Penetrating the Impossible Space. Zanele Muholi's 'Somnyama Ngonyama' in London," Arthrob, 28 August 2017. <accessed on 19 July, 2020>

37. I use this terminology to which Muholi resorts in their own work, although I am aware that the terms have been critiqued, notably for entrenching essentialist conceptions of gender. See Madhumita Lahiri, "Crimes and Corrections: Bride Burners, Corrective Rapists, and Other Black Misogynists," Feminist Africa 15 (2011): 121-34 and Kylie Thomas, "Homophobia, Injustice and 'corrective Rape' in Post-apartheid South Africa," Cape Town: Centre for the Study of Violence and Reconciliation, 2013, 4-5.

38. There is a history of LGBTQ+ activism in South Africa that predates the end of apartheid. See the GALA Queer Archive.

39. Mussai, "Archive of the Self,"195.

40. W.E.B. Du Bois, The Souls of Black Folks (1903; Oxford: Oxford University Press, 2007): 7-8.

41. Muholi, Somnyama Ngonyama, 7.

42. Muholi, Somnyama Ngonyama, 161.

43. Christine Eyenne, "On Thembeka I," in Muholi, Somnyama Ngonyama, 158.

44. And, indeed, in many places around the world where non-white sexual minorities are particularly exposed to homophobic and transphobic violence. 
45. This is not to diminish the very high levels of violence in the country as a whole, in particularly violence directed against migrant workers and domestic violence.

46. Muholi, Somnyama Ngonyama, 86.

47. Muholi, Somnyama Ngonyama, 167.

48. Mussai, "Archive of the Self," 187 . Square brackets in the original text.

49. Muholi, Somnyama Ngonyama, 46.

50. Muholi, Somnyama Ngonyama, 5.

51. Muholi, Somnyama Ngonyama, 73.

52. Muholi, Somnyama Ngonyama, 74-75.

53. Mussai, "Archive of the Self," 194.

54. Muholi, Somnyama Ngonyama, 2.

55. Muholi, Somnyama Ngonyama, 16.

56. Muholi, Somnyama Ngonyama, 139.

57. Muholi, Somnyama Ngonyama, 119.

58. Mussai, "Archive of the Self," 185.

59. Muholi, Somnyama Ngonyama, 24.

60. A method of summary execution consisting in burning a victim alive by forcing a rubber tyre filled with petrol around their chest and arms and setting it on fire. See for instance Pumla Gobodo-Madikizela, "Remorse, Forgiveness, and Rehumanization: Stories from South Africa," Journal of Humanistic Psychology, 42-1 (2002): 7-32 and Riedwaan Moosage, "A Prose of Ambivalence: Liberation Struggle Discourse on Necklacing," Kronos 36-1 (2010). <accessed 26 April, 2021> Tyres, burning or otherwise, have long featured in Muholi's work, and beyond in the work of South African visual artists. For a joint reading of the iconography of tyres in installation videos by Berni Searle and Zanele Muholi, see Helene Strauss, "Spectacles of Promise and Disappointment: Political Emotion and Quotidian Aesthetics in Video Installations by Berni Searle and Zanele Muholi," Safundi 15-4 (2014): 471-495. <accessed on 27 April, 2021>

61. Muholi, Somnyama Ngonyama, 33.

62. Mussai, "Archive of the Self," 180.

63. Mark Gevisser, "Zanele Muholi: Dark Lionness," The Economist, 1843 Magazine, 5 June 2018. $<$ accessed on 24 July, 2020>

64. See for instance M. Neelika Jayawardane's comment about Somnyama II, Oslo, 2015, in which Muholi wears an enormous wig: “Nicholaes Maes's Portrait of a Gentleman (ca 1675-80)-which I've never been able to look at without thinking how hilarious and kitschy the subject looks, comes to mind. In Muholi's self-portrait, the kitsch remains, but it is used for something other than foppery. The look on Muholi's face tells us to wipe away our grins." Jayawardane, "Heeding the Dark Lionness's Call," 173.

65. Muholi, Somnyama Ngonyama, front page and 61.

66. Mussai, "Archive of the Self," 182.

67. https://www.instagram.com/p/CAcN-hdl2hg/ <accessed on 24 July, 2020>

68. The online resource and news portal SAcoronavirus indicates that on 3 July 2021 only 3.3 million people had been vaccinated, which corresponds to approximately $5 \%$ of the population. https://sacoronavirus.co.za/2021/07/03/update-on-covid-19-03-july-2021/ <accessed on 4 July, $2021>$

69. Cara Anna, "Coronavirus Cases Spike in South Africa and India, Exposing Inequalities in Virus Treatment," Time Magazine, 11 July 2020. <accessed on 24 July, 2020> 


\section{ABSTRACTS}

This article looks at South African photographer and visual activist Zanele Muholi's ongoing project Somnyama Ngonyama and argues that it continues Muholi's lifework of decolonizing the canon of representations of Black bodies, especially Black female bodies. In this series of selfportraits, Muholi challenges conventional representations of Black bodies as they appear in Western art history, in ethnographic photography or in the conventional mass media. Repurposing familiar objects, the pictures also encode sophisticated puzzles that express a sense of stifling under the pressure of racist misrepresentations. However, they also counter this epistemic violence by performing ambiguous gestures of appearing or disappearing, challenging the racist norms that would confine black bodies in certain spaces while barring them from others.

\section{INDEX}

Keywords: Zanele Muholi, photography, South Africa, self-portrait, epistemic disobedience

\section{AUTHOR}

\section{ALEXANDRA POULAIN}

Alexandra Poulain is Professor of postcolonial literature at the Sorbonne Nouvelle (France). She has published widely on modern and contemporary Irish drama and performance, with a special focus on Yeats and Beckett. Her latest book Irish Drama, Modernity and the Passion Play (Palgrave, 2016) looks at rewritings of the Passion narrative as a modality of political resistance in Irish plays from Synge to the present day. Her current research focuses on decolonial projects in the visual arts and on cultural and artistic representations of shame in postcolonial drama and art. She is the current President of the SAES and of the International Yeats Society. 